\title{
Efficiency Increase of Enterprise Activity on the Basis of Marketing Tools
}

\author{
Ismagilov R.Kh. \\ A.N. Tupolev National Research Technical \\ University \\ Kazan, Russia \\ gumerov_anvar@mail.ru
}

\author{
Gumerov A.V. \\ A.N. Tupolev National Research Technical \\ University \\ Kazan, Russia \\ gumerov_anvar@mail.ru
}

\begin{abstract}
The methods of economic efficiency increase of refueling enterprise activity is studied. It is shown that in modern conditions the activity in terms of mono-product business limits growth of profitability of the enterprise and increases market risks. In terms of market pressure of big oil producing enterprises and also competition increase in the sphere of retail sale, there is tightening of activity conditions in oil products enterprises. This conclusion is confirmed by the results of the economic analysis of the activities of a particular filling organization. It is proved that in modern conditions it is necessary to improve measures directed toward sales profitability increase, as well as increase customer loyalty through the use of modern marketing tools.

Specific offers are created to increase the profitability of the company through the use of customers' loyalty tools, the use of cost-sharing methods, cross-marketing.
\end{abstract}

Keywords - gas station; profitability; loyalty; participation economy; cross-marketing.

\section{INTRODUCTION}

The analysis of oil products market showed that there are difficult times for the retail trade enterprises and the conditions of their activity become worse. During 2017, the price of automotive gasoline AI-92 increased by $9.53 \%$, AI-95 by $7.20 \%$, summer diesel fuel-by $5.47 \%$ and aviation kerosene-by $18.22 \%$. While in 2016, prices for petroleum products lagged significantly behind the rate of inflation. Within the last three years, it can be stated that the prices increase for oil products in all segments corresponds with the level of inflation.

The situation in 2018 was more complicated. For the period from 31.12.17 to 14.05 .18 according to Rosstat, the price of motor gasoline AI-92 increased by $3.5 \%$, AI- 95 by $3.4 \%$, diesel fuel - by $4.17 \%$ with an increase in inflation by $1.2 \%$.

Since March 2018, prices started to rise following the prices on world markets and following the rise in excise. By 21.05.2018 wholesale gasoline prices exceeded retail prices. The main reasons for the fuel prices increase are the following: rising world prices, unscheduled repairs of refineries by oil companies, insufficient supply of motor fuels by oil companies at stock exchanges. The tax component in the final price of each liter of motor fuel sold in the country is about $60 \%$.
This leads to profitability decrease at oil products retail trade enterprises and the need for searching a set of methods to improve the efficiency of their work.

\section{LITERATURE REVIEW}

To analyze the degree of the problem study, we examined several sources. So, marketing and service questions as presented in works $[8,10,11,12,15,16]$, the questions of tools application for clients' loyalty improvement are presented in works $[13,14,18,19,20]$, questions concerning specific aspects of applications, theory of inventive problem solving are presented in works [7, 21], questions concerning the psychology of achievement and goal setting are studied in the work by Gordeeva [9], Prigozhin [17], the aspects of projects planning are discussed in works [1-6].

\section{RESEARCH METHODOLOGY}

In our opinion, the solution of the considered problem is reasonable to carry out on the basis of the invention objectives solution theory methodical tools (TIOS).

The main aim of the theory is the idea that any system initially exists with an excess resource, so, in any system there are always hidden resources to improve the efficiency of its operation. The aim of the researcher is to find these hidden resources using the developed algorithms and techniques of TIOS.

One of the main tools of TIOS is the use of environmental resources, the search for contradictions in the development of the system individual parts, the formulation of the ideal final result( IFR), as well as the use of proven techniques for resolving contradictions and standards for their application.

Through the use of TIOS tools, it is possible to raise the efficiency during the search for solutions, neglect weak or outdated solutions and radically improve the results of the enterprise in general.

The scientific novelty of the article lies in the formulation of a set of measures to improve the efficiency of the retail trade of oil products, which are based on the following principles: the use of free or easily accessible resources of the external environment, the involvement of personal goal-setting systems and customers' aim achievement into the loyalty program of the company, alternative trading systems hybridization, non-competing economic entities combination into partner networks. 
These principles were used to develop fundamentally new solutions to improve the profitability of the retail trade in petroleum products, taking into account the specifics of this activity type. A characteristic feature of the developed solutions are low costs for their implementation and priority in the use of the customers themselves available resources, as well as the use of external resources.

The authors conducted a research on the basis of oil products-LLC "Fuel company" retail trade separate enterprise. The analysis of the company's activities shows that in 2018 the profitability of own capital was $9 \%$. Profitability of own capital for the last two years decreased by $10.7 \%$. As you can see, there is a fall in profitability of own capital of the company, in particular due to the fall in profitability of sales. It is reasonable to create a complex of measures, directed toward enterprise income increase.

For profit growth we have formulated the following marketing directions:

\section{The growth of customers' loyalty;}

2. Related businesses development.

This article presents a set of ideas for the development of customer loyalty. So, at some gas stations in Europe to increase the flow of customers, the management decided to distribute free beautiful coffee glasses to everyone. At some stations, coffee was also poured free of charge. On the way to the solution, the businessman faced a number of problems: If you distribute thermo cups for free, there will be a pandemonium of those who want to get glasses. If you pour coffee for free, then a large queue will also be created. If you pour coffee for refueling, the cafe inside the gas station becomes not necessary. station?

How to guarantee the return of the customer to the gas

\section{How to regulate the flow of people?}

\section{RESULTS}

1) A special thermo-cup with a special neck was created. This was done so that the cup could be used only in places, where there are coffee machines for such cups.

2) The cup was given free of charge when refueling the machine. Coffee was given free of charge to customers if they took the fuel paying 500 rubles.

3) In order reduce the cost of coffee and cups, cups had advertisements.

4) Advertisement about the action at the gas station was nowhere. For the buyer it was a surprise, but word-of-mouth advertising worked.

After coming to the gas station and refueling for 500 rubles or more, the client received: a thermos cup, free coffee, plus a mini-brochure, where it was written, why and by whom the promotion was carried out. Gas stations attendance increased by $20 \%$, and the number of cars refueling for 500 rubles and more increased by $1517 \%$.
Another area of work is improving the quality of customer service. For this purpose active work on feedback formation and strengthening with clients through the website of the company is conducted. On this site, customers can leave information and express their complaints about the quality of service. Information on the measures taken is posted on the company's website. This increases customers' loyalty.

The third direction of the company work is the formation of a customers' loyalty program. Within the framework of this program, the following activities are introduced into the company's activities: free tasting of natural coffee and other beverages; drawing of valuable prizes, connected with the holidays, such as New Year, Motherland defender's Day, international Women's day; 6\% discounts provision for cash and Bank cards for petroleum products; drawing cars among customers, who have proven their loyalty to the company; development of partnership programs with the shopping center "Essen" and cross-marketing campaigns.In order to increase customers' loyalty, we offer a new tool that involves the active participation of the company in stimulating the achievement of goals by the client.

\section{Idea №2. Awarding the client for achieving the goals.}

The client and his goal-setting and goal-achieving system are at the forefront, and the company awards the client for achieving his personal goals through a system of discounts and bonuses when buying the company's products. The goals that the client sets for himself can be of a very different nature, and depend on the personality of the client and his own desires. That is, we do not push the client to achieve goals that are beneficial to the company and do not impose our system of values on him or offer him to purchase products that he absolutely does not need or discounts depending on the volume of purchased products. The idea is the principle of participatory economics, where the client and the firm work together to achieve the goal of the client rather than the firm. In practice, this concept can be implemented through the following algorithm:

1. The firm offers the client to enter into contract of setting and achieving the goal.

2. The client chooses the sphere of goal-setting from the list offered by the company or offers his own sphere of goalsetting.

3. The firm checks whether the chosen goal of the client corresponds with legal, moral, ethical and other principles of activity.

4. After that, a contract is signed for the achievement of the goal and the time of its achievement is determined. As a rule, this is a period of one week.

5. A week later, the client comes to the company and brings proof of achieving their own goal.

6. The company as a bonus offers the customer a discount on the purchase of products. The size of the discount depends on the degree and difficulty of achieving the goal.

As an example, let's consider the example of cooperation between the firm and the client. The promotion goes like this: 
"Earn a discount owing to your own mind."The essence of the action: during the week, the student studies and receives grades in the diary. Next, calculates the amount of points for all grades during the week and gets a discount on the products presented in the company. That is, the student himself earns the right to a discount. As part of this promotion, the amount of discounts depends on the number of points for the week. The system of discounts for the collected number of points in the diary for the week. 15-25 points-3\%, 25-35 points-5\%, $35-45$ points-7 $\%, 45-60$ points- $10 \%$, more than 60 points$15 \%$.

Here is an example of calculating the purchase price. For example, the purchase price was: 690 rubles. If you get a discount of $15 \%$, the price will be 592 rubles. The prize is 104 rubles. That is, there is a direct relationship between the personal results of the student in the intellectual sphere and the level of his income. The main slogan of the campaign: "Bring a diary with grades and get a $15 \%$ discount!". This concept implies a wide range of goals in different areas. The approximate sphere of goal setting is presented in table 1 .

TABLE I. SPHERE OF GOAL SETTING

\begin{tabular}{|l|l|l|l|}
\hline № & $\begin{array}{l}\text { Sphere of } \\
\text { goal setting }\end{array}$ & $\begin{array}{l}\text { The approximate criterion of } \\
\text { purpose }\end{array}$ & Target audience \\
\hline 1 & Educational & $\begin{array}{l}\text { Number of points received per } \\
\text { week }\end{array}$ & Lovers to learn \\
\hline 2 & Intellectual & $\begin{array}{l}\text { Number of tasks solved in a } \\
\text { week or ideas submitted at } \\
\text { work }\end{array}$ & $\begin{array}{l}\text { Those, who like } \\
\text { to brainstorm }\end{array}$ \\
\hline 3 & Sport & $\begin{array}{l}\text { Number of sports exercises } \\
\text { performed }\end{array}$ & Sports fan \\
\hline 4 & Technical & $\begin{array}{l}\text { The number of fines during } \\
\text { operation of a car }\end{array}$ & $\begin{array}{l}\text { Fans } \\
\text { technology of }\end{array}$ \\
\hline
\end{tabular}

Idea №3. Intellectual quest.

Another direction of customer loyalty growth is the distribution of leaflets with interesting texts on various topics: historical, sports, art, music, technical, scientific and so on. In this text there are a lot of mistakes of various kinds-logical, grammatical, punctuation, factual, and so on. The client receives a leaflet with the text and must find mistakes in it. Depending on how many mistakes the customer finds in the text, the amount of discounts or bonuses when purchasing the company's products changes. The dependence of the text content in the leaflet and the target audience is described in table 2 .

TABLE II. DEPENDENCE OF THE TEXT CONTENT IN THE LEAFLET AND THE TARGET AUDIENCE

\begin{tabular}{|c|c|c|c|}
\hline № & $\begin{array}{l}\text { Type of } \\
\text { mistakes in the } \\
\text { text }\end{array}$ & The essence of the mistake & $\begin{array}{l}\text { Target } \\
\text { audience }\end{array}$ \\
\hline 1 & $\begin{array}{l}\text { Spelling, } \\
\text { punctuation }\end{array}$ & $\begin{array}{l}\text { On the forest traveled bikers on } \\
\text { motorcycles and machines }\end{array}$ & $\begin{array}{l}\text { The lovers } \\
\text { of the } \\
\text { Russian } \\
\text { language }\end{array}$ \\
\hline 2 & Logical & $\begin{array}{l}\text { The wind blows because the } \\
\text { trees are swaying }\end{array}$ & $\begin{array}{l}\text { Fans of } \\
\text { logic }\end{array}$ \\
\hline 3 & Historical & $\begin{array}{l}\text { World War II ended in } 1950 \\
\text { with the USA victory over } \\
\text { Germany }\end{array}$ & $\begin{array}{l}\text { History } \\
\text { lovers }\end{array}$ \\
\hline 4 & Geographical & $\begin{array}{l}\text { People are happy to travel to the } \\
\text { Maldives to admire the world from } \\
\text { the top of Everest }\end{array}$ & $\begin{array}{l}\text { Fans of } \\
\text { geography }\end{array}$ \\
\hline
\end{tabular}

\section{Idea № 4. Cross marketing}

UDS game is a complete business solution that includes a mobile application and tools to optimize business processes. The UDS game mobile app is one of the innovative means to retain and attract customers. A discount program called UDS game is an app that doesn't need to be paid for. It is installed in a mobile phone or tablet. With its help, a person can take advantage of discounts or other bonuses that are provided in institutions that are part of the system with this name. This application is partly reminiscent of social networks, partlynetwork marketing.

The user registers, adds friends, recommends them certain restaurants or entertainment centers. From their activity, he gets additional advantages. Key advantage. A discount program called UDS game eliminates the need to carry a large number of plastic cards in your wallet, which are so easily lost. The more often you use the app, the more bonuses you get.

\section{Idea №5. Related business development}

Shops and cafes at gas stations in Russia, following the global trend, from a simple service transformed into a fullfledged grocery retail. Sales of related and food products, fast food and coffee are generating more revenue, and gas stations are already competing with retailers.

Many analytical agencies have noted changes in consumers' behavior: the price factor has become a stronger influence on the choice of goods and places of consumption. But the gas station-retail is more of a pulse channel, on the principle of "saw-bought" up to $90 \%$ of purchases are made. And for such goods, there is really a decrease in demand. We are now going through a transformation from a pulse store to a convenient one-we are introducing categories such as dairy products, a minimum set of groceries, several items of bread, salads, a priority set of household chemicals, etc. Our goal is to form a sustainable tradition of consumption at shops and cafes at gas stations.

Summing up the proposed practical recommendations, it can be noted that their implementation should be comprehensive, systematic and involve a wide range of company's personnel to improve the financial results of the enterprise.

\section{CONCLUSION}

In accordance with the revealed problems it was offered to realize the events in terms of several directions: measures taking concerning profitability of the enterprise increase; events creation concerning business activity of the enterprise increase and clients' loyalty increase; events creation, which improve the effectiveness of interaction with partner business activities.

For clients' loyalty increase we offered the tool, based on awarding a client for his own aims achievement, not the aims of the enterprise. Owing to this attention focusing is provided on the interests of the client himself, his personal system of target setting, which has a positive influence on motivation and client's satisfaction. 
An important direction is also cross-marketing tools use owing to net interaction of enterprises of different activity spheres in terms of mutual partner discount programs. It helps to broaden the resources use for activity effectiveness increase among enterprises of retail oil products sale.

Finally, one more direction of the enterprise effectiveness increase is products diversification, adding it with accompanying kinds of products and giving the function of a supermarket to a gas station. It provides clients flow increase and additional income for the organization.

\section{References}

[1] Craig Larman, Bas Vodde. Practices for Scaling Lean \& Agile Development: Large, Multisite, and Offshore Product Development with Large-Scale Scrum. Moscow: Addison-Wesley Professional. 2010, 624 .

[2] Craig Larman, Bas Vodde. Scaling Lean \& Agile Development: Thinking and Organizational Tools for Large-Scale Scrum. M.: Addison-Wesley Professional. 2008, 368.

[3] Demyanova O.V., Ishkova E.I., Sotov D.I., Khisamova E.D., Gataullin I.I. The main features of strategy formation for sustainable companies' development in economic crisis conditions. Journal of engineering and applied sciences 2017, vol. 12(19), pp. 4948-4951.

[4] Demyanova O.V., Zaidullina C.N., Novoselov M. Development of the company due to forming of innovative structure. Journal of engineering and applied sciences. 2017, vol. 12(19), pp. 4943-4947.

[5] Kashif Ali Sulemani and Muhammad Nadeem Nasir. Communication Support to Scrum Methodology in Offshore Project. M.: LAP Lambert Academic Publishing. 2010, 84.

[6] Ken Schwaber. Agile Project Management with Scrum. Moscow. 2004, 192.

[7] S.Litvin, A.Lyubomirskiy. Trends of engineering systems evolution. Guide. Gen3Partners, Inc. 2003, 186.

[8] Current price situation analysis at the market of oil products (Site of Federal antimonopoly service. URL: https://fas.gov.ru/news/24992)

[9] Gordeeva T. Psychology of motivation of achievement. Moscow: Smysl (Essence). 2015, 336.

[10] Gornostaeva Zh.V.,. Duvanskaya E.B, Alekhina E.S. Activity organization and planning of service enterprises. Manual. Rostov-onDon: Phoenix. 2016, 320.

[11] Gribov V.D., Leonov A.L. Economics of service enterprise. Moscow: KnoRus. 2011, 280.

[12] John Showl "First rate service as a competitive advantage". Moscow: Alpina Publisher. 2019, 384.

[13] Mann I., Turusin D “Contact points". Moscow: MIF. 2013, 100

[14] Carl Sewell, Paul Brown "Clients for the whole life". Moscow: MIF. 2010, 304.

[15] Kotler F. Marketing. Management. Analysis, planning, introduction, control. The 2nd edition, changed Saint-Petersburg : "Piter" publishing house. 2017.

[16] Leonardo Ingileri, Mika Solomon. Outstanding service, perfect income. Moscow: MIF. 2013, 224.

[17] Prigozhin A.I. Aims and values. New methods of work with the future. Moscow: Delo ANKH. 2010, 432.

[18] Rick Barrera Exceeding expectations. Moscow: Eksmo. 2007, 272

[19] R. Sysodia, Dzhag Shet, David Volf. Enterprises, which bring love. Moscow: Balance Business Books. 2011.

[20] Fred Raikheld, R. Marki True loyalty. Moscow: MIF. 2013, 342.

[21] Alexsandr S. Kuznetsov. Russian Professor's meeting. Russian Journal of Physical Education and Sport. 2019, 14(1), pp. 17-22. DOI: 10.14526/2070-4798-2019-14-1-18-24

[22] Shpakovskiy N.A. TRIZ: Practice of target invention. Moscow: Forum. 2011, 336. 